\title{
MMP13 wt Allele
}

National Cancer Institute

\section{Source}

National Cancer Institute. MMP13 wt Allele. NCI Thesaurus. Code C102922.

Human MMP13 wild-type allele is located in the vicinity of $11 \mathrm{q} 22.3$ and is approximately $13 \mathrm{~kb}$ in leng th. This allele, which encodes collagenase 3 protein, is involved in collagen catabolism. Mutation of the gene is associated with both spondyloepimetaphyseal dysplasia Missouri type and metaphyseal anadysplasia type 1. 